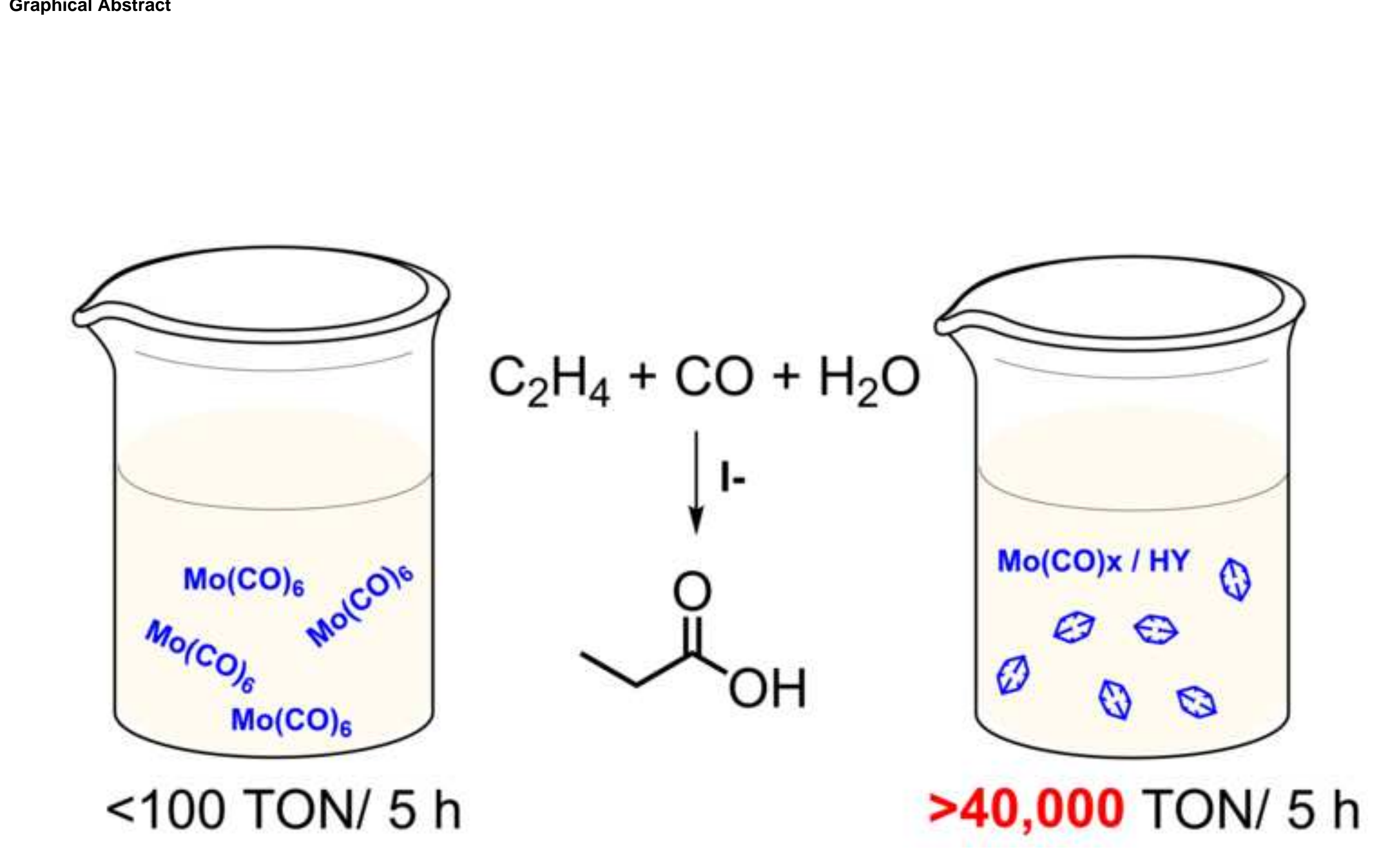

$\mathrm{C}_{2} \mathrm{H}_{4}+\mathrm{CO}+\mathrm{H}_{2} \mathrm{O}$

$>40,000 \mathrm{TON} / 5 \mathrm{~h}$

.

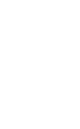$$
\text { (1) }
$$ 


\title{
Increased Productivity in Ethylene Carbonylation by Zeolite-Supported Molybdenum Carbonyls
}

\author{
Chieh-Chao Yang ${ }^{1,2}$, Sara Yacob, ${ }^{1}$ Beata A. Kilos ${ }^{3}$, David G. Barton ${ }^{3}$, Eric Weitz ${ }^{2}$ and \\ Justin M. Notestein ${ }^{1 *}$ \\ ${ }^{I}$ Chemical \& Biological Engineering, Northwestern University, Evanston 60208 IL (USA) \\ ${ }^{2}$ Department of Chemistry, Northwestern University, Evanston 60208 IL (USA) \\ ${ }^{3}$ The Dow Chemical Company, Core R\&D, Midland 48674 MI (USA)
}

\begin{abstract}
:
Ethylene carbonylation to propionic acid is a powerful route to the synthesis of oxygenates. $\mathrm{Mo}(\mathrm{CO})_{6}$ is a known homogenous catalyst for this reaction. When supported on HY zeolite, prepared by incipient wetness impregnation from pentane or by vapor deposition, turnover numbers dramatically increase to over 40,000 in $5 \mathrm{~h}$ of reaction, particularly for the supports with lower $\mathrm{Si} / \mathrm{Al}$ ratios. Diffuse reflectance UV-visible spectra and thermogravimetric analysis indicate that lower $\mathrm{Si} / \mathrm{Al}$ ratios promote more and stronger interactions between $\mathrm{Mo}(\mathrm{CO})_{6}$ and the support, leading to higher reactivity under liquid-phase reaction conditions. Although some leaching occurs under these conditions, the active catalyst is the supported $\mathrm{Mo}(\mathrm{CO})_{\mathrm{x}} / \mathrm{HY}$, and the recovered catalysts are still stable and active for ethylene carbonylation with turnover numbers exceeding $30,000 \mathrm{~mol}$ propionic acid/mol of Mo over $5 \mathrm{~h}$ at $190^{\circ} \mathrm{C}$. FTIR provides evidence for the formation and stabilization of under-coordinated carbonyl species during heat treatment, and such sub-carbonyls are known to be relevant in previously-established catalytic mechanisms.
\end{abstract}

Keywords: heterogeneous catalysis, carbonylation, ethylene, promotion, molybdenum, metal carbonyl, Y-type zeolite, impregnation

\section{Introduction}

Carbonylation of alkenes to form carboxylic acids or their esters is typically carried out with homogeneous catalysts. We and others have reported on the reactivity of $\mathrm{Mo}(\mathrm{CO})_{6}$ and other group VI metal carbonyls with iodide promoters for ethylene carbonylation to form propionic anhydride and propionic acid. [1,2] A practical drawback of using $\mathrm{Mo}(\mathrm{CO})_{6}$ in solution is that separation of the products from the solvent and catalyst is difficult. More fundamentally, the carbonylation mechanism requires the formation of open coordination sites on Mo, which can lead to catalyst deactivation through the formation of Mo metal or oxide particles. The possible advantages of using supported metals for ethylene carbonylation has been noted. Studies of heterogeneous catalysis for ethylene carbonylation have been limited to silica- and zeolite supported precious metal ( $\mathrm{Pd}, \mathrm{Rh}, \mathrm{Ir}, \mathrm{Pt}, \mathrm{Ru})$ complexes using bromide promoters and these have not focused on the reaction mechanism. [3, 4] There are no reports we are aware of for ethylene carbonylation using supported metal carbonyls.

Although not previously studied for ethylene carbonylation, there have been many studies of the structure of $\mathrm{Mo}(\mathrm{CO})_{6}$ supported on zeolites by vapor deposition [5-14], or by impregnation $[6,15]$ typically with the goal of synthesizing metallic Mo or Mo oxides. For example, using FTIR, Howe et al. [6] reported that at least three different sub- 
carbonyls $\left(\mathrm{Mo}(\mathrm{CO})_{4}\right.$, dinuclear anion $\mathrm{Mo}_{2}(\mathrm{CO})_{10}{ }^{2-}$ and an unassigned species) were formed by heating $\mathrm{Mo}(\mathrm{CO})_{6}$ adsorbed on $\mathrm{HY}$ or $\mathrm{NaY}$. These sub-carbonyls formed reversibly between 50 and $150^{\circ} \mathrm{C}$. Further evacuation above $200^{\circ} \mathrm{C}$ partially oxidized (on $\mathrm{HY}$ ) or reduced (on $\mathrm{NaY}$ ) the molybdenum, resulting in species that did not re-adsorb appreciable quantities of $\mathrm{CO}$. Okamoto et al. [7, 8] also observed the reversible formation of Mo sub-carbonyls at $\sim 100^{\circ} \mathrm{C}$ on $\mathrm{HY}$ and $\mathrm{NaY}$, and their decomposition by $150^{\circ} \mathrm{C}$. In that study, the sub-carbonyl species was assigned as $\mathrm{Mo}(\mathrm{CO})_{3}$. Given this evidence for stabilization of sub-carbonyls over Y-type zeolites, one would hypothesize that they would be excellent supports for ethylene carbonylation catalysts.

In this paper, $\mathrm{Mo}(\mathrm{CO})_{6}$ supported on zeolite $\mathrm{HY}$ with $\mathrm{Si} / \mathrm{Al}$ ratios of 15,30 , and 40 was prepared by impregnation and vapor deposition under water- and air-free conditions. TGA-MS, and FTIR and DRUV-visible spectroscopy were used to identify the nature of the supported Mo carbonyls. These materials were then shown to be extraordinarily effective catalysts for ethylene carbonylation - TON exceed 40,000 in $5 \mathrm{~h}$ of reaction when suspended in acetic acid / water solutions and in the presence of a set of iodide promoters.

\section{Experimental}

\subsection{Catalyst preparation}

Supported $\mathrm{Mo}(\mathrm{CO})_{6}$ catalysts were prepared by incipient wetness impregnation (IM) and vapor deposition (VD) under water- and air-free conditions. $\mathrm{Mo}(\mathrm{CO})_{6}$ and Y-type zeolite (proton form $\mathrm{HY}, \mathrm{Si} / \mathrm{Al}=15,30,40$ ) were obtained from Sigma-Aldrich and Zeolyst, respectively. HY zeolite has a unit cell size of $24.2 \AA$, surface area of $700-800$

$\mathrm{m}^{2} / \mathrm{g}$, and 0.03 weight $\% \mathrm{Na}_{2} \mathrm{O}$. Solid state ${ }^{27} \mathrm{Al}$ NMR shows some extra-framework $\mathrm{Al}$ in all the zeolites (see supporting information Figure $\mathrm{S} 1$ ), and $\mathrm{NH}_{3}$ temperature programmed desorption gives $\mathrm{H}^{+} / \mathrm{Al}$ ratios of $0.27,0.39$, and 0.21 for $\mathrm{Si} / \mathrm{Al}=15,30$, and 40 respectively. (see supporting information Table S2, Figure S2 and S3.) Note that only absorption on Brønsted acid sites was found on the bare HY support using $\mathrm{NH}_{3}$-TPD-IR. Prior to synthesis, $\mathrm{Mo}(\mathrm{CO})_{6}$ and the zeolite were held under dynamic vacuum $(<30$ mtorr) for 2 days at room temperature and $200^{\circ} \mathrm{C}$, respectively, to remove physisorbed water. For the impregnation samples (denoted as IM in the following text and figures), the constituents used to prepare these samples were all transferred to an Ar-filled controlled atmosphere box. $\mathrm{Mo}(\mathrm{CO})_{6}$ was then dissolved in anhydrous pentane $(\geq 99 \%$, with less than $0.001 \%$ water content), and the minimum wetting volume of the solution was added to the zeolite sample to give materials with 0.2-3.2 wt\% Mo. Catalysts are denoted $\mathrm{Mo}(\mathrm{CO})_{\mathrm{x}} / \mathrm{HY}$ in general, and $\mathrm{Mo}(\mathrm{CO})_{\mathrm{x}} / \mathrm{HY} 15, \mathrm{Mo}(\mathrm{CO})_{\mathrm{x}} / \mathrm{HY} 30$, and $\mathrm{Mo}(\mathrm{CO})_{\mathrm{X}} / \mathrm{HY} 40$, for the specific HY supports. The as-prepared samples (IM) were left stirring gently inside the glove box until dry, and used without further calcination. For the vapor deposition samples (denoted as VD in the following text and figures), $30 \mathrm{mg}$ $\mathrm{Mo}(\mathrm{CO})_{6}$ and $500 \mathrm{mg}$ of the pre-dried HY were evacuated separately to $<80$ mtorr on a Schlenk line. The valve to the pump was closed, and the two vessels were connected for $2 \mathrm{~h}$ to allow vapor transfer from room temperature $\mathrm{Mo}(\mathrm{CO})_{6}$ to the $\mathrm{HY}$ flask held at $0^{\circ} \mathrm{C}$ by an ice bath. The loaded HY was finally evacuated at $<30$ mtorr at room temperature for $30 \mathrm{~min}$ to remove excess $\mathrm{Mo}(\mathrm{CO})_{6}$.

\subsection{Ethylene carbonylation}


Reactants and solvents were obtained from Sigma-Aldrich and used without further purification. Following the conditions of our prior studies [2], the standard reaction mixture consisted of $1.3 \mathrm{mmol}$ of tetrabutyl phosphonium iodide (TBPI), $76 \mathrm{mmol}$ of ethyl iodide (EtI), $460 \mathrm{mmol}$ of water and $760 \mathrm{mmol}$ of acetic acid in a total volume of 51 $\mathrm{mL}$. A $300 \mathrm{~mL}$ Hastelloy® C reactor was used for ethylene carbonylation experiments. This autoclave was filled with the liquid mixture and $\mathrm{Mo}(\mathrm{CO})_{6}$-based catalysts. The reactor was stirred mildly (c.a. $300 \mathrm{rpm}$ ), and was pressurized with 10 bar $\mathrm{N}_{2}$ and vented. This $\mathrm{N}_{2}$ pressurization and purge was repeated 4 times to remove gaseous and dissolved $\mathrm{O}_{2} .10 \pm 1$ bar $\mathrm{H}_{2}$, (99.999\%, Airgas), $10 \pm 1$ bar ethylene (99.999\%, Airgas), and $10 \pm 1$ bar CO (99.9995\%, Airgas) were sequentially charged into the reactor at room temperature to reach a total pressure of $30 \pm 1$ bar. These pressures correspond to $91 \pm 8$ mmol each of $\mathrm{CO}, \mathrm{C}_{2} \mathrm{H}_{4}$ and $\mathrm{H}_{2}$ being charged into the headspace of the reactor; corresponding yields are thus accurate to $\pm 10 \%$. The reactor was heated and the stirring speed was increased to $900 \mathrm{rpm}$. Within 1 hour, the sample temperature and pressure equilibrated at $190^{\circ} \mathrm{C}$ and $50-52$ bar. Reaction time $\mathrm{t}=0$ was designated to be when the reaction temperature reached $190^{\circ} \mathrm{C}$. The pressure decreased to $12-14$ bar after $5 \mathrm{~h}$ of reaction (24-26 bar after $1 \mathrm{~h}$ of reaction) after cooling to room temperature; an indication of consumption of $\mathrm{CO}$ and ethylene. After the reactor was cooled to room temperature, a liquid aliquot sample was passed through a $0.1 \mu \mathrm{m}$ PTFE filter for GC analysis using an Agilent 7890A GC-FID with a HP-INNOWAX column (50 m x $0.2 \mathrm{~mm} \times 0.4 \mu \mathrm{m})$. Propanoate yield was calculated relative to the added CO. Propionic acid (PA), ethyl propionate (EP), propionaldehyde, ethyl acetate, diethyl ether (DEE) and ethanol signals were calibrated against known standards. The latter three are condensation products between EtI and solvent water or acetic acid. The headspace in most experiments was sampled after cooling to room temperature, and no additional volatile products, such as ethane, acetaldehyde, or dimethyl ether, were detected.

2.3. Catalyst characterization

Mo loading was quantified with a Varian Vista MPX ICP-OES. Molybdenum standards for instrument calibration were prepared from a $1000 \mathrm{mgL}^{-1}$ AAS standard solution in the range of 0-30 ppm of Mo. Materials were dissolved in $48 \%$ hydrofluoric acid (HF) and diluted with ultra-pure water before analysis. X-ray diffraction (XRD) patterns were collected using a Rigaku X-ray diffractometer over the range 5-40 $2 \theta$ and $\mathrm{Cu} \mathrm{K} \alpha(\lambda=1.54059 \AA)$ radiation. Step size, slit widths, and dwell times were kept constant for all materials.

Diffuse reflectance UV-visible (DRUV-vis) spectra were collected with a UV-3600 Shimadzu spectrophotometer equipped using a Harrick Praying Mantis high temperature reaction chamber to allow measurements at elevated temperature and under gas flow. Polytetrafluoroethylene (PTFE) was used as the background spectrum. The catalysts were heated from ambient temperature to $180^{\circ} \mathrm{C}\left(5^{\circ} \mathrm{C} / \mathrm{min}\right)$ in Helium at $30 \mathrm{~mL} / \mathrm{min}$. Reflectance data were recorded and transformed into the Kebulka-Munk (K-M) function.

Thermogravimetric analysis (TGA) was performed in a TA Instruments Q500 thermogravimetric analyzer with an evolved gas analysis furnace connected to a Pfeiffer Thermostar Q200 mass spectrometer through a fused $\mathrm{SiO}_{2}$ capillary column maintained at $200^{\circ} \mathrm{C}$. The catalyst was heated from ambient temperature to $200^{\circ} \mathrm{C}\left(5^{\circ} \mathrm{C} / \mathrm{min}\right)$ in helium at $100 \mathrm{~mL} / \mathrm{min}$. No change was seen in the $\mathrm{m} / \mathrm{z}=14$ intensity after the first minute, 
indicating that air was rapidly purged from the system, and that the $\mathrm{m} / \mathrm{z}=28$ intensity was due to evolved $\mathrm{CO}$ from decarbonylation of $\mathrm{Mo}(\mathrm{CO})_{6}$.

FT-IR spectra were recorded with a Thermo Scientific Nicolet 6700 infrared spectrometer equipped with a mercury cadmium telluride (MCT) detector. Each spectrum

was the average of 128 scans taken at $4 \mathrm{~cm}^{-1}$ resolution. The catalyst was supported onto a highly IR transmissive tungsten grid $\left(\sim 4 \mathrm{~cm}^{2}\right)$ mounted in a custom-built transmission IR cell [16]. The IR cell was sealed with $\mathrm{CaF}_{2}$ windows and connected to a mechanical pumped gas manifold. After $1 \mathrm{~h}$ of vacuum at 20 mtorr, the catalyst was resistively heated from 30 to $180^{\circ} \mathrm{C}\left(5^{\circ} \mathrm{C} / \mathrm{min}\right)$ and the IR spectra were recorded.

\section{Results}

3.1. Promotion in catalytic turnover over $\mathrm{Mo}(\mathrm{CO})_{\mathrm{x}} / \mathrm{HY}$

Table 1 shows the results for iodide-promoted ethylene carbonylation using supported and unsupported $\mathrm{Mo}(\mathrm{CO})_{6}$. Product selectivity toward propionic acid is high $(>95 \%)$ in all cases. To achieve nearly complete conversion for the unsupported $\mathrm{Mo}(\mathrm{CO})_{6}$ in $5 \mathrm{~h}$ requires $\sim 1000 \mu \mathrm{mol} \mathrm{Mo}(\mathrm{CO})_{6}$, and reducing the Mo reactor charge to $\sim 180 \mu \mathrm{mol}$ $\mathrm{Mo}(\mathrm{CO})_{6}$ decreases yields to $16 \%$. The turnover number is less than 100 in that case. The behavior of this soluble catalyst has been investigated previously by us and others. Increasing $\mathrm{CO}$ partial pressures are inhibitory, [1] but complete conversion is possible under these conditions up to at least 15 bar CO pressure. [2] We have shown that ethyl iodide is a promoter and neither a co-catalyst nor a stoichiometric reagent, as shown by the fate of ${ }^{13} \mathrm{C}$ labeled species, among other experiments. [2] Likewise, complete conversion of stoichiometric $\mathrm{CO}$ and ethylene is possible at much lower ethyl iodide loadings, [2] but the relatively high amounts used here help illuminate differences amongst catalysts. Finally, the added $\mathrm{H}_{2}$ presumably serves to retard water-gas shift and to maintain the Mo in an active state.

In contrast to the productivity of the soluble catalyst, the supported catalyst $\mathrm{Mo}(\mathrm{CO})_{\mathrm{x}} / \mathrm{HY} 15$ reaches nearly complete conversion after $5 \mathrm{~h}$ for reactor loadings as low as $6 \mu \mathrm{mol} \mathrm{Mo}$, corresponding to a TON as high as 15,000. Further lowering the reactor loading to $2 \mu \mathrm{mol}$ Mo leads to 40,000 TON over $5 \mathrm{~h}$ of reaction. TON and yields at 170 $\mu \mathrm{mol}$ Mo decrease with increasing $\mathrm{Si} / \mathrm{Al}$ ratio of the support, but all the supported catalysts outperform the unsupported $\mathrm{Mo}(\mathrm{CO})_{6}$. Bare $\mathrm{HY}$ supports show no PA production, and adding both $\mathrm{Mo}(\mathrm{CO})_{6}$ and $\mathrm{HY}$ to the autoclave exhibits similar activity to the equal amount of the unsupported $\mathrm{Mo}(\mathrm{CO})_{6}$, demonstrating the synergistic effect of $\mathrm{Mo}(\mathrm{CO})_{6}$ loaded into the zeolite. Alone, zeolite HY shows no yield of PA. Although the VD catalyst has much lower Mo loadings $(0.1 \mathrm{wt} \%$ vs $2.4 \mathrm{wt} \%)$, it reaches similar TON $(34,000)$ as the IM catalyst when similar amounts of Mo are added to the reactor.

Heating the catalysts in flowing $\mathrm{He}(30 \mathrm{~mL} / \mathrm{min})$ at $200^{\circ} \mathrm{C}$ has no impact on the loading (as shown in supporting information Table S1), whereas analysis of the used catalysts shows some leaching under reaction conditions (Table 1); Mo(CO) $/ \mathrm{HY} 15$ loses $85 \%$ of its Mo down to a level of $0.3 \mathrm{wt} \%$. The catalysts with higher Si/Al ratios leach even further, losing $90 \%$ of their Mo. Interestingly, the Mo/Al ratios for the spent catalysts were around 0.04 in all cases. The VD catalyst does not undergo any significant leaching, consistent with its starting Mo/Al ratio of 0.01 being below the apparent threshold at which the system is stable with respect to leaching. The combination of high $\mathrm{CO}$ pressure, additives such as the tetrabutylphosphonium cation, and the condensed 
phase all likely contribute to the leaching from all but a small fraction of potential adsorption sites, in spite of the demonstrated thermal stability of these catalysts in helium.

Importantly, when the spent $\mathrm{Mo}(\mathrm{CO})_{\mathrm{x}} / \mathrm{HY} 15$ is recovered by filtration, washed with c.a. $250 \mathrm{~mL}$ of de-ionized water, and reused in a second reaction, a similarly high PA yield and TON $(36,000)$ is obtained. In this case, the reactor Mo loading was similar for the two cases, achieved by adding much more of the spent catalyst. Thus, even though only a small fraction of the Mo complexes are stable with respect to leaching, all seem to be similarly reactive.

Table 2 shows the dependence on $\mathrm{Mo}(\mathrm{CO})_{6}$ loading for iodide-promoted ethylene carbonylation. The reactions were performed under identical conditions as shown in Table 1. However, since many of the entries in Table 1 reached nearly complete conversion in $5 \mathrm{~h}$ reaction, reactions were also run for $1 \mathrm{~h}$ to allow for the determination of an approximation of the initial rates. When the reactor charge of Mo is controlled at 20 $\mu \mathrm{mol}, 2.4 \% \mathrm{Mo}(\mathrm{CO})_{6} / \mathrm{HY} 15$ achieves $\sim 2,000 \mathrm{TON}$ for PA (42\% yield) in $1 \mathrm{~h}$. For all loadings on $\mathrm{Mo}(\mathrm{CO})_{6} / \mathrm{HY} 15$ and 30 , the $1-\mathrm{h}$ TON is not dependent on $\mathrm{Mo}(\mathrm{CO})_{6}$ loading, and is approximately 1,900 and 1,600, respectively. These catalysts also leach down to $\mathrm{Mo} / \mathrm{Al} \sim 0.04$, but the near-constant TON again suggests that all of the supported Mo species are catalytically similar, irrespective of loading. These results also show the catalytic relevance of Mo, as opposed to the Al sites in the zeolite, since the latter increase in number dramatically across the entries in Table 2, without a corresponding increase in yield. In contrast, the $1-\mathrm{h}$ TON decreases from 1,700 TON to 70 with increasing loading for $\mathrm{Mo}(\mathrm{CO})_{6} / \mathrm{HY} 40$. This high-silica zeolite does appear to create a distribution of Mo active sites, especially for high Mo loading (3.0 wt\%). In the latter case where the activity drops precipitously, the Mo per original acid site $\left(\mathrm{Mo} / \mathrm{H}^{+}\right)$is 3.7 , much higher than $\mathrm{Mo}(\mathrm{CO})_{6} / \mathrm{HY} 15$ and $\mathrm{Mo}(\mathrm{CO})_{6} / \mathrm{HY} 30$, suggesting that inactive $\mathrm{Mo}$ is deposited above a certain threshold. These results indicate that TON increase rather uniformly for supported Mo. More details about the nature of these immobilized Mo species will be discussed in 3.2 .

\subsection{Identification of sub-carbonyls on $\mathrm{Mo}(\mathrm{CO})_{\mathrm{x}} / \mathrm{HY}$}

The catalysts listed in Table 1 were used for all characterizations that follow. As shown in Fig. 1, XRD patterns of the three impregnated $\mathrm{Mo}(\mathrm{CO})_{6} / \mathrm{HY}$ catalysts show no disruption of the zeolite framework and no crystalline $\mathrm{Mo}(\mathrm{CO})_{6}$ (three major peaks at 15.5, 16.6 and $17.3^{\circ} 2 \theta$ ). DRUV-vis spectra, in Fig. 2, show two major bands at 240 and $290 \mathrm{~nm}$, both assigned to MLCT (metal-to-ligand charge transfer) features between Mo and CO. [17] Yokota and coworkers previously assigned the $290 \mathrm{~nm}$ band and the shoulder at $330 \mathrm{~nm}$ to $\mathrm{Mo}(\mathrm{CO})_{6}$ on $\mathrm{NaY}$, while the $245 \mathrm{~nm}$ band was assigned to $\mathrm{Mo}(\mathrm{CO})_{5}$. [11] Likewise, Perutz et al. reported the UV-vis spectra of unsupported $\mathrm{Mo}(\mathrm{CO})_{6}$ during photo-decomposition in methane at $20 \mathrm{~K}$. A feature at $285 \mathrm{~nm}$ was uniquely assigned to $\mathrm{Mo}(\mathrm{CO})_{6}$, whereas Mo sub-carbonyls had blue-shifted absorption band - e.g. $247 \mathrm{~nm}$ for $\mathrm{Mo}(\mathrm{CO})_{5}$. [18] Here, we assign the $240 \mathrm{~nm}$ feature to subcarbonyls $\operatorname{Mo}(\mathrm{CO})_{\mathrm{x}}(\mathrm{x}<6)$ and the $290 \mathrm{~nm}$ nature to fully-coordinated carbonyls $\mathrm{Mo}(\mathrm{CO})_{6}$. We do not attempt to distinguish between sub-carbonyls based on these data. For the impregnated samples, Fig. 2 (a) to (c), the $290 \mathrm{~nm}$ feature increases with increasing $\mathrm{Si} / \mathrm{Al}$ ratio, suggesting that more of the Mo remains as $\mathrm{Mo}(\mathrm{CO})_{6}$ for the low- 
acid samples. As shown in Fig. 2 (d), the $290 \mathrm{~nm}$ feature is very weak for the vapordeposited sample $(0.1 \mathrm{wt} \%)$.

DRUV-vis spectra were also recorded while heating the supported Mo carbonyls in helium, and the intensity changes at 290 and $240 \mathrm{~nm}$ are summarized in Fig. 2 (e) and 2 (f). During heating, there is a slight increase in K-M pseudo-absorbance as temperature increases, likely due to black body radiation. However, as the temperature reaches 110$120^{\circ} \mathrm{C}$, absorption at $290 \mathrm{~nm}$ drops as $\mathrm{Mo}(\mathrm{CO})_{6}$ decomposes. The absorbance at $240 \mathrm{~nm}$ begins to decrease at slightly higher temperatures, typically near $130^{\circ} \mathrm{C}$, suggesting sequential decarbonylation. The temperature for complete decarbonylation increases with increasing Si/Al ratio, from $\sim 140^{\circ} \mathrm{C}$ to $160^{\circ} \mathrm{C}$ to $170^{\circ} \mathrm{C}$ for $\mathrm{Mo}(\mathrm{CO})_{\mathrm{X}} / \mathrm{HY} 15, \mathrm{HY} 30$, and HY40, respectively. The decomposition temperature of the latter sample is similar to that of unsupported $\mathrm{Mo}(\mathrm{CO})_{6}$.

In addition to the temperature of complete decarbonylation, Fig. 2 (e) and 2 (f) also show an increasing ratio of the $290 \mathrm{~nm}$ to $240 \mathrm{~nm}$ features with increasing Si/Al ratio, indicating that the fraction of sub-carbonyls is highest for the $\mathrm{Si} / \mathrm{Al}=15$ sample at all temperatures. The low loadings of the vapor-deposited sample decreases the $\mathrm{I}_{290} / \mathrm{I}_{240}$ ratio to $\sim 0.7$ at $120^{\circ} \mathrm{C}$, whereas the higher-loaded impregnation sample has a ratio of 1.0 at $120^{\circ} \mathrm{C}$. Overall, DRUV-vis spectra indicate that there are relatively more sub-carbonyls on the $\mathrm{Si} / \mathrm{Al}=15$ support and for low loadings, at all temperatures. Described alternately, lower $\mathrm{Mo} / \mathrm{Al}$ ratios promote the formation and stabilization of Mo sub-carbonyls.

TGA-MS, as shown in Fig. 3, shows the thermal decomposition of supported carbonyls, with a maximum in the rate of mass loss near $110^{\circ} \mathrm{C}$ for all the $\mathrm{HY}$ supported catalysts. An additional decomposition peak at $140^{\circ} \mathrm{C}$ is observed for $\mathrm{Mo}(\mathrm{CO})_{\mathrm{x}} / \mathrm{HY} 40$. As noted in Table S1, no significant Mo loss occurs with these thermal treatments. The signal at $\mathrm{m} / \mathrm{z}=28$, Fig. 3(b), tracks the mass change, Fig. 3(a), consistent with these events being decarbonylation. In view of the DRUV-vis results discussed earlier, the first peak is assigned to decomposition of sub-carbonyls $\operatorname{Mo}(\mathrm{CO})_{\mathrm{x}}(\mathrm{x}<6)$ and strongly adsorbed $\mathrm{Mo}(\mathrm{CO})_{6}$, while the additional higher temperature peak is assigned to decomposition of physically-adsorbed $\mathrm{Mo}(\mathrm{CO})_{6}$. Using the mass loss between 60 and $200^{\circ} \mathrm{C}$, Fig. 3(c) reports a $\mathrm{CO} / \mathrm{Mo}$ ratio. This value is an upper limit since loss of adsorbed water may also be measured. The supported catalysts show an upper limit of $\sim 6 \mathrm{CO} / \mathrm{Mo}$, consistent with the starting $\mathrm{Mo}(\mathrm{CO})_{6}$. The $\mathrm{CO} / \mathrm{Mo}$ ratio is always lower for HY15 and HY30 than it is for HY40, consistent with the DRUV-vis results showing proportionally more $\mathrm{Mo}(\mathrm{CO})_{6}$ for the HY40 support. The low loading of the vapor-deposited sample precludes a detailed analysis. However, only a single weight loss peak was observed at $70^{\circ} \mathrm{C}$, which includes both water loss and decarbonylation from sub-carbonyls, consistent with a prior literature report [7].

More detailed information about sub-carbonyl species is obtained from FTIR spectroscopy under thermal treatment in vacuo, shown in Fig. 4 (a) to (c). Difference spectra are shown, where the spectrum taken after heating to $170^{\circ} \mathrm{C}$ is used as the background for each of the lower-temperature spectra. Nearly identical traces are obtained if spectra are baselined against the bare HY support, indicating that complete decarbonylation is achieved at $170^{\circ} \mathrm{C}$ in vacuo, in accordance with DRUV-vis and TGA results. Unfortunately, the low loadings of the VD-synthesized catalysts did not permit meaningful analysis by FTIR. 
Crystalline $\mathrm{Mo}(\mathrm{CO})_{6}$ has a strong absorption at $2002 \mathrm{~cm}^{-1}$ and a weak shoulder at $1970 \mathrm{~cm}^{-1}$. (see supporting information Figure S4) Others have assigned features to $\mathrm{Mo}(\mathrm{CO})_{6}$ [19] in the zeolite pore structure (1990 and $\left.2002 \mathrm{~cm}^{-1}\right)$, weakly physisorbed $\mathrm{Mo}(\mathrm{CO})_{6}\left(2118\right.$ and $\left.1970 \mathrm{~cm}^{-1}\right)[8,11], \mathrm{Mo}(\mathrm{CO})_{5}$ or strongly chemisorbed $\mathrm{Mo}(\mathrm{CO})_{6}$ $\left(2045\right.$ and $\left.1950 \mathrm{~cm}^{-1}\right)$ [8, 11], $\mathrm{Mo}(\mathrm{CO})_{4}\left(2020\right.$ and $\left.1918 \mathrm{~cm}^{-1}\right)$ [11] and $\mathrm{Mo}(\mathrm{CO})_{3}(1925$

$\mathrm{cm}^{-1}$ ) $[8,11,20]$. These catalysts show a continuum of features from $\sim 1900 \mathrm{~cm}^{-1}$ to $\sim 2060 \mathrm{~cm}^{-1}$ as synthesized, and they all decompose at higher temperatures. Table 3 summarizes the IR stretching frequencies for the catalysts based on the literature reported assignments.

The Mo carbonyl IR features are not well resolved in the freshly-prepared $\mathrm{Mo}(\mathrm{CO})_{6} / \mathrm{HY}$ catalysts. Figs. 4 (d) to (f) plot the changes of integrated area in different regions (2060-2015, 2015-1960 and 1960-1900 $\left.\mathrm{cm}^{-1}\right)$ during heating. We assign the area between $2015-1960 \mathrm{~cm}^{-1}$ as resulting from adsorbed $\mathrm{Mo}(\mathrm{CO})_{6}$. These are the predominant species, consistent with TGA-MS results that correspond to a $\mathrm{CO} / \mathrm{Mo}$ ratio near 6 . The combined area of 2060-2015 and 1960-1900 $\mathrm{cm}^{-1}$ represent various Mo sub-carbonyls, $\mathrm{Mo}(\mathrm{CO})_{\mathrm{x}}$, including $\mathrm{Mo}(\mathrm{CO})_{4}$ and $\mathrm{Mo}(\mathrm{CO})_{3} \cdot \mathrm{Mo}(\mathrm{CO})_{6}$ and all $\mathrm{Mo}(\mathrm{CO})_{\mathrm{x}}$ decrease monotonically during thermal treatment in vacuo and disappear completely above $140^{\circ} \mathrm{C}$, consistent with the TGA-MS results. As with TGA-MS and DRUV-vis, the total area of the $\mathrm{Mo}(\mathrm{CO})_{\mathrm{x}}$ features decreases with increasing $\mathrm{Si} / \mathrm{Al}$ ratio at any given temperature. The reader is cautioned against attempting to make quantitative comparisons of the temperature responses across TGA, DRUV-vis, and FTIR due to the very different cell geometries in each case. [footnote]

It should be mentioned that no evidence is seen for dinuclear Mo carbonyls $\left[\mathrm{Mo}_{2}(\mathrm{CO})_{8}\right]$ or $\left[\mathrm{Mo}_{2}(\mathrm{CO})_{10}\right]$ which have been reported over $\mathrm{HY}$ at 1931,1854 and 1753 $\mathrm{cm}^{-1}$. [6, 21] The absence of these features is likely due to the relatively low loadings for our catalysts, corresponding to a maximum of 3 Mo per HY unit cell, as compared with 17 Mo per $\mathrm{NaY}$ unit cell in a literature report [21].

[footnote: Though samples are uniformly heated in TGA, gas sweeps across the powder surface; gas passes through the powder bed in DRUV-vis, the sample has known thermal gradients and the DRUV-vis cell has a large dead volume; gas flows and temperatures are most uniform in the FTIR wire-grid cell. This will change, for example, the extent to which weakly-adsorbed $\mathrm{Mo}(\mathrm{CO})_{6}$ is removed during pretreatments and how quickly the detected chemical species respond to changes in temperature.]

\section{Discussion and Conclusions}

This work reports on remarkable increases in catalytic turnover in iodide-promoted ethylene carbonylation for Mo carbonyls immobilized on zeolite HY relative to the analogous homogenous system [2], while maintaining $>95 \%$ selectivity to propionic acid. Productivity is the highest for low $\mathrm{Si} / \mathrm{Al}$ ratios. The turnover numbers for $\mathrm{Mo}(\mathrm{CO})_{\mathrm{x}} / \mathrm{HY} 15$ can exceed 40,000 in $5 \mathrm{~h}$, representing at least a 400-fold improvement over the analogous homogenous systems using $\mathrm{Mo}(\mathrm{CO})_{6}$. This turnover number can be regarded as a lower limit to the rate since the reaction may terminate in less than $5 \mathrm{~h}$. This increase in TON is not achieved by using simple combinations of $\mathrm{Mo}(\mathrm{CO})_{6}$ and the zeolite in the same reactor, and turnovers are relatively insensitive to reuse and to Mo loading and method of deposition, at least up to the values tested $(2.4 \mathrm{wt} \%$, or 0.25 
$\mathrm{Mo} / \mathrm{Al}$ for $\mathrm{HY}$ zeolite with $\mathrm{Si} / \mathrm{Al}=15$ ). These latter experiments demonstrate that the active catalyst is Mo-based and indeed heterogeneous, in spite of reaction conditions that leach down the Mo loading until very low loadings of Mo/Al $<0.05$. It is suspected that much of the leaching occurs after the reaction is complete, and that the particular choice of promoters is partially responsible for the leaching. Work is underway to mitigate leaching to make catalysts that are more productive on a per-gram basis.

We ascribe the enhancement in catalyst productivity to two phenomena. The first is the increase in local acidity. TON and rate increase with decreasing $\mathrm{Si} / \mathrm{Al}$ and greater acid site density of the support. Our previous mechanistic study indicates that the propionic acid product is liberated from the Mo active site by an acid, regenerating the key Mo hydride intermediate. [2] Higher acid site densities will therefore ensure that this is not a step limiting to catalyst activity.

Secondly, and likely more importantly, is the ability of the zeolite support to stabilize Mo sub-carbonyls. Our recent mechanistic findings [2] demonstrate that undercoordinated Mo sites are required for activation of the ethyl iodide promoter and formation of the crucial Mo hydride. Thus, stabilization of the sub-carbonyls affects the kinetics of the reaction since a larger fraction of the Mo is in an active form at a given $\mathrm{CO}$ partial pressure than in the analogous homogeneous systems. Others have reported an inverse dependence of $\mathrm{CO}$ partial pressure on the carbonylation rate of the soluble $\mathrm{Mo}(\mathrm{CO})_{6}$ catalyst [1], which confirms the kinetic relevance of sub-carbonyls.

DRUV-vis and TGA-MS provide evidence for two classes of supported Mo carbonyls, and those assigned as sub-carbonyls are relatively more common on lower $\mathrm{Si} / \mathrm{Al}$ supports and the lower loadings of the vapor deposition-synthesized sample. This is consistent with the observed enhancement in rate and TON because we believe that the sub-carbonyls (or some fraction of them) are the active species. It has been frequently reported that Mo sub-carbonyls are the major species when materials are synthesized by direct vapor deposition of $\mathrm{Mo}(\mathrm{CO})_{6}$ over zeolite supports. [5-7] The overall decarbonylation temperature is also lower for lower Si/Al supports and for the VDsynthesized sample, indicating stronger surface-Mo interactions for those samples. Finally, FTIR spectroscopy provides direct evidence that $\mathrm{Mo}(\mathrm{CO})_{\mathrm{x}}$ sub-carbonyls are formed over the as-synthesized catalysts and they decarbonylate sequentially as the temperature increases in vacuo, suggesting that stabilization of these sub-carbonyls may be responsible for the large increases in catalytic turnover for ethylene carbonylation using the supported catalysts.

We are currently optimizing reaction conditions to better understand and further exploit these enormous productivity enhancements to an industrially-relevant catalytic transformation.

\section{Acknowledgements}

The authors acknowledge the financial support of The Dow Chemical Company. The CleanCat Core facility acknowledges funding from the Department of Energy (DEAC02-06CH11357) used for the purchase of the gas chromatography equipment and $\mathrm{NH}_{3}$-TPD. XRD characterization was done at the J.B. Cohen X-Ray Diffraction Facility supported by the MRSEC program of the National Science Foundation (DMR-1121262) at Northwestern University. ICP-OES and Solid State NMR were performed at the Northwestern University Integrated Molecular Structure Education and Research Center 
with funding provided by NSF (DMR-0521267). The authors thank Yuyang Wu at IMSERC for his technical assistance for solid state ${ }^{27} \mathrm{Al}-\mathrm{NMR}$. 
Table 1. Ethylene carbonylation ${ }^{1}$ for unsupported and zeolite(HY)-supported $\mathrm{Mo}(\mathrm{CO})_{6}$.

\begin{tabular}{|c|c|c|c|c|c|c|c|}
\hline \multirow[b]{3}{*}{ catalyst } & \multicolumn{5}{|c|}{ fresh } & \multicolumn{2}{|c|}{ used } \\
\hline & \multicolumn{3}{|c|}{ Mo loading ${ }^{2}$} & \multirow{2}{*}{$\begin{array}{c}\mathrm{TON}^{3} \\
(\mathrm{~mol} / \mathrm{mol} \mathrm{Mo})\end{array}$} & \multirow{2}{*}{$\begin{array}{c}\text { Yield }^{4} \\
(\%)\end{array}$} & \multicolumn{2}{|c|}{ Mo loading } \\
\hline & $(\mathrm{wt} \%)$ & $\mathrm{Mo} / \mathrm{Al}$ & $(\mu \mathrm{mol})$ & & & $(\mathrm{wt} \%)$ & $\mathrm{Mo} / \mathrm{Al}$ \\
\hline \multirow{2}{*}{$\mathrm{Mo}(\mathrm{CO})_{6}$} & - & - & 180 & 83 & 16 & - & - \\
\hline & - & - & 1000 & 96 & 99 & - & - \\
\hline \multirow{4}{*}{$\mathrm{Mo}(\mathrm{CO})_{6} / \mathrm{HY}(\mathrm{Si} / \mathrm{Al}=15)(\mathrm{IM})$} & 2.4 & 0.25 & 2 & 40500 & 89 & 0.3 & 0.03 \\
\hline & & & 6 & 15300 & 101 & & \\
\hline & & & 20 & 4550 & 101 & & \\
\hline & & & 170 & 540 & 101 & & \\
\hline $\mathrm{Mo}(\mathrm{CO})_{6} / \mathrm{HY}(\mathrm{Si} / \mathrm{Al}=30)(\mathrm{IM})$ & 2.3 & 0.47 & 170 & 410 & 76 & 0.2 & 0.04 \\
\hline $\mathrm{Mo}(\mathrm{CO})_{6} / \mathrm{HY}(\mathrm{Si} / \mathrm{Al}=40)(\mathrm{IM})$ & 2.1 & 0.57 & 170 & 290 & 53 & 0.2 & 0.05 \\
\hline Mixture of $\mathrm{Mo}(\mathrm{CO})_{6}$ and $\mathrm{HY}$ & - & - & 170 & 82 & 15 & - & - \\
\hline Used $\mathrm{Mo}(\mathrm{CO})_{6} / \mathrm{HY}(\mathrm{Si} / \mathrm{Al}=15)(\mathrm{IM})$ & 0.3 & 0.03 & 2 & 35500 & 78 & - & - \\
\hline $\mathrm{Mo}(\mathrm{CO})_{6} / \mathrm{HY}(\mathrm{Si} / \mathrm{Al}=15)(\mathrm{VD})$ & 0.1 & 0.01 & 3 & 33700 & 107 & 0.1 & 0.01 \\
\hline \multicolumn{8}{|c|}{ 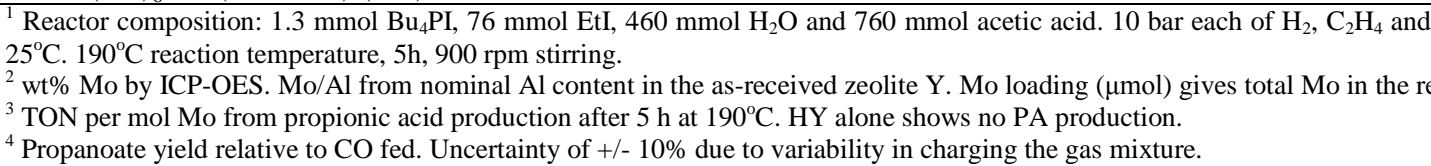 } \\
\hline
\end{tabular}

Table 2. Ethylene carbonylation ${ }^{1}$ for various loading of impregnated zeolite(HY)supported $\mathrm{Mo}(\mathrm{CO})_{6}$.

\begin{tabular}{|c|c|c|c|c|c|c|c|c|}
\hline \multirow[b]{3}{*}{ catalyst } & \multicolumn{5}{|c|}{ fresh } & \multicolumn{3}{|c|}{ Used $^{6}$} \\
\hline & \multicolumn{3}{|c|}{ Mo loading $^{2}$} & \multirow{2}{*}{$\begin{array}{c}\mathrm{TON}^{4} \\
(\mathrm{~mol} / \mathrm{mol}-\mathrm{Mo})\end{array}$} & \multirow{2}{*}{$\begin{array}{c}\text { Yield }^{5} \\
(\%)\end{array}$} & \multicolumn{3}{|c|}{ Mo loading } \\
\hline & $(\mathrm{wt} \%)$ & $\mathrm{Mo} / \mathrm{Al}$ & $\left(\mathrm{Mo} / \mathrm{H}^{+}\right)^{3}$ & & & $(\mathrm{wt} \%)$ & $\mathrm{Mo} / \mathrm{Al}$ & $\mathrm{Mo} / \mathrm{H}^{+}$ \\
\hline \multirow{3}{*}{$\mathrm{Mo}(\mathrm{CO})_{6} / \mathrm{HY}(\mathrm{Si} / \mathrm{Al}=15)$} & 0.3 & 0.03 & 0.1 & 1990 & 39 & 0.3 & 0.03 & 0.1 \\
\hline & 0.6 & 0.06 & 0.2 & 1780 & 36 & 0.2 & 0.02 & 0.1 \\
\hline & 2.4 & 0.25 & 0.9 & 2030 & 42 & 0.3 & 0.03 & 0.1 \\
\hline \multirow{3}{*}{$\mathrm{Mo}(\mathrm{CO})_{6} / \mathrm{HY}(\mathrm{Si} / \mathrm{Al}=30)$} & 0.3 & 0.06 & 0.2 & 1520 & 31 & 0.3 & 0.05 & 0.2 \\
\hline & 0.6 & 0.12 & 0.3 & 1560 & 32 & 0.1 & 0.03 & 0.1 \\
\hline & 3.2 & 0.68 & 1.6 & 1670 & 36 & 0.2 & 0.04 & 0.1 \\
\hline \multirow{3}{*}{$\mathrm{Mo}(\mathrm{CO})_{6} / \mathrm{HY}(\mathrm{Si} / \mathrm{Al}=40)$} & 0.2 & 0.05 & 0.3 & 1770 & 36 & 0.1 & 0.03 & 0.1 \\
\hline & 0.4 & 0.10 & 0.5 & 1160 & 24 & 0.1 & 0.03 & 0.1 \\
\hline & 3.0 & 0.84 & 3.7 & 72 & 2 & 0.1 & 0.03 & 0.1 \\
\hline
\end{tabular}

${ }_{1}$ Reactor composition: $1.3 \mathrm{mmol} \mathrm{Bu} 4 \mathrm{PI}, 76 \mathrm{mmol} \mathrm{EtI,} 460 \mathrm{mmol} \mathrm{H}_{2} \mathrm{O}$ and $760 \mathrm{mmol}$ acetic acid. 10 bar each of $\mathrm{H}_{2}, \mathrm{C}_{2} \mathrm{H}_{4}$ and $\mathrm{CO}$ at $25^{\circ} \mathrm{C} .190^{\circ} \mathrm{C}$ reaction temperature, $1 \mathrm{~h}, 20 \mu \mathrm{mol}$ Mo in the reaction, $900 \mathrm{rpm}$ stirring.

${ }^{2}$ as-synthesized catalysts. wt $\%$ Mo from ICP. Mo/Al from nominal $\mathrm{Al}$ content in the as-received zeolite $\mathrm{Y}$.

${ }^{3} \mathrm{Mo} / \mathrm{H}^{+}$relative to acidity of the bare $\mathrm{HY}$ support from $\mathrm{NH}_{3}$-TPD (Table S2).

${ }_{5}^{4} \mathrm{TON}$ from propionic acid production after $1 \mathrm{~h}$ at $190^{\circ} \mathrm{C}$.

${ }^{5}$ Propanoate yield relative to $\mathrm{CO}$ fed.

Table 3. IR carbonyl stretching frequencies of the species observed during thermal decomposition over zeolite(HY)-supported $\mathrm{Mo}(\mathrm{CO})_{6}$.

\begin{tabular}{lll}
\hline species & $v\left(\mathrm{~cm}^{-1}\right)$ & assignment \\
\hline I & 2002 & unsupported $\mathrm{Mo}(\mathrm{CO})_{6}[19]$ \\
II & $2118,1990,1970$ & physisorbed $\mathrm{Mo}(\mathrm{CO})_{6}[8,11]$ \\
III & 2045,1950 & chemisorbed $\mathrm{Mo}(\mathrm{CO})_{6}[6]$ or $\mathrm{Mo}(\mathrm{CO})_{5}[8,11]$ \\
IV & 2020,1920 & $\mathrm{Mo}(\mathrm{CO})_{4}[11]$ \\
V & 1925 & $\mathrm{Mo}(\mathrm{CO})_{3}[8,11,20]$ \\
\hline
\end{tabular}




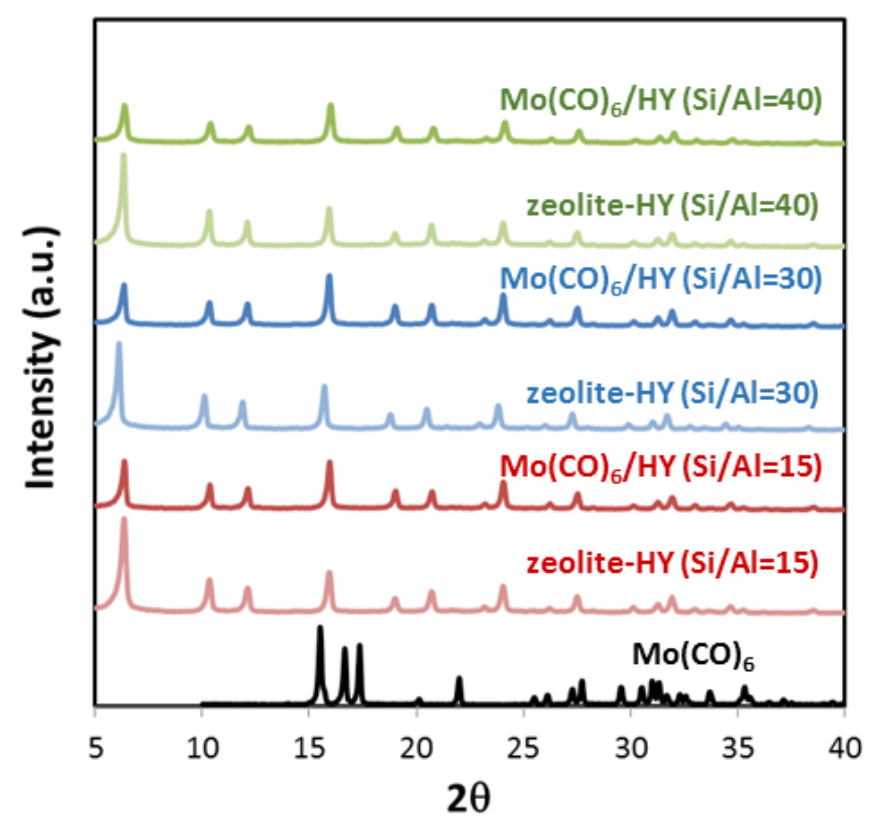

Fig. 1 XRD patterns of the unsupported and impregnated zeolite(HY)-supported $\mathrm{Mo}(\mathrm{CO})_{6}$. 
(a)

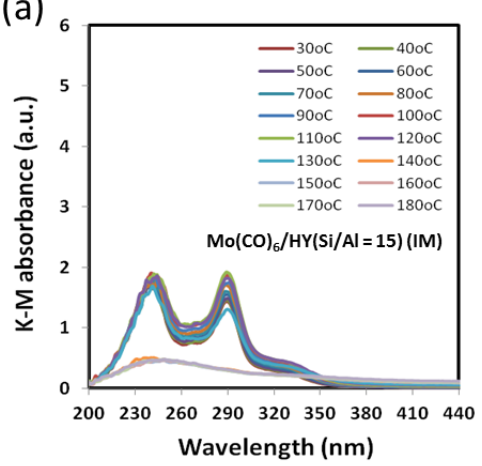

(d)

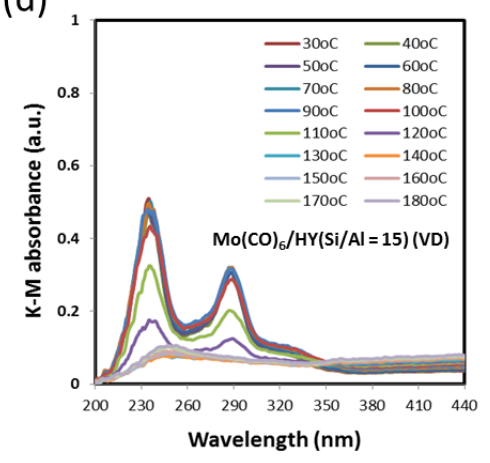

(b)

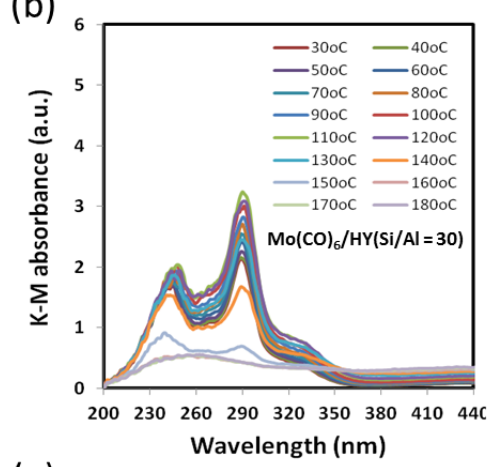

(e)

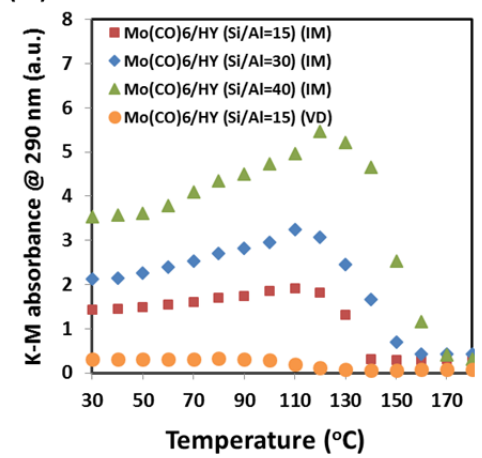

(c)

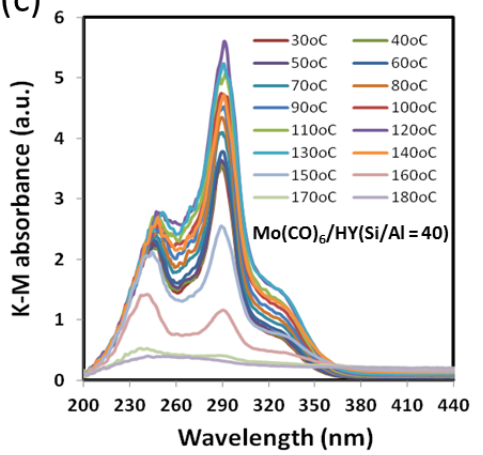

(f)

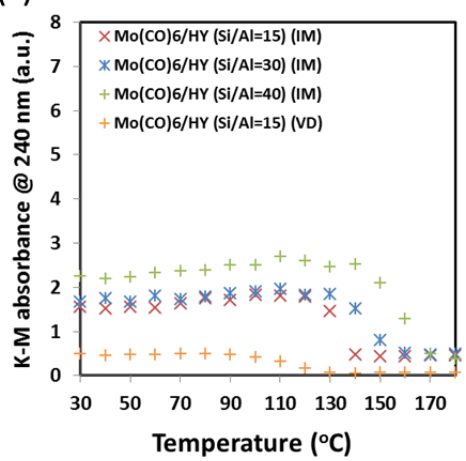

Fig. 2 Diffuse reflectance UV-visible spectra of (a) $\mathrm{Mo}(\mathrm{CO})_{6} / \mathrm{HY}(\mathrm{Si} / \mathrm{Al}=15)$ (IM), (b) $\mathrm{Mo}(\mathrm{CO})_{6} / \mathrm{HY}(\mathrm{Si} / \mathrm{Al}=30) \quad(\mathrm{IM}), \quad$ (c) $\quad \mathrm{Mo}(\mathrm{CO})_{6} / \mathrm{HY}(\mathrm{Si} / \mathrm{Al}=40) \quad$ (IM) and (d) $\mathrm{Mo}(\mathrm{CO})_{6} / \mathrm{HY}(\mathrm{Si} / \mathrm{Al}=15)$ (VD). The catalysts were heated from 30 to $180^{\circ} \mathrm{C}$ in $\mathrm{He}$ $\left(30 \mathrm{~mL} / \mathrm{min}, 5^{\circ} \mathrm{C} / \mathrm{min}\right)$. (e) Intensity changes at $290 \mathrm{~nm}$ during heating. (f) Intensity changes at $240 \mathrm{~nm}$ during heating. 
(a)
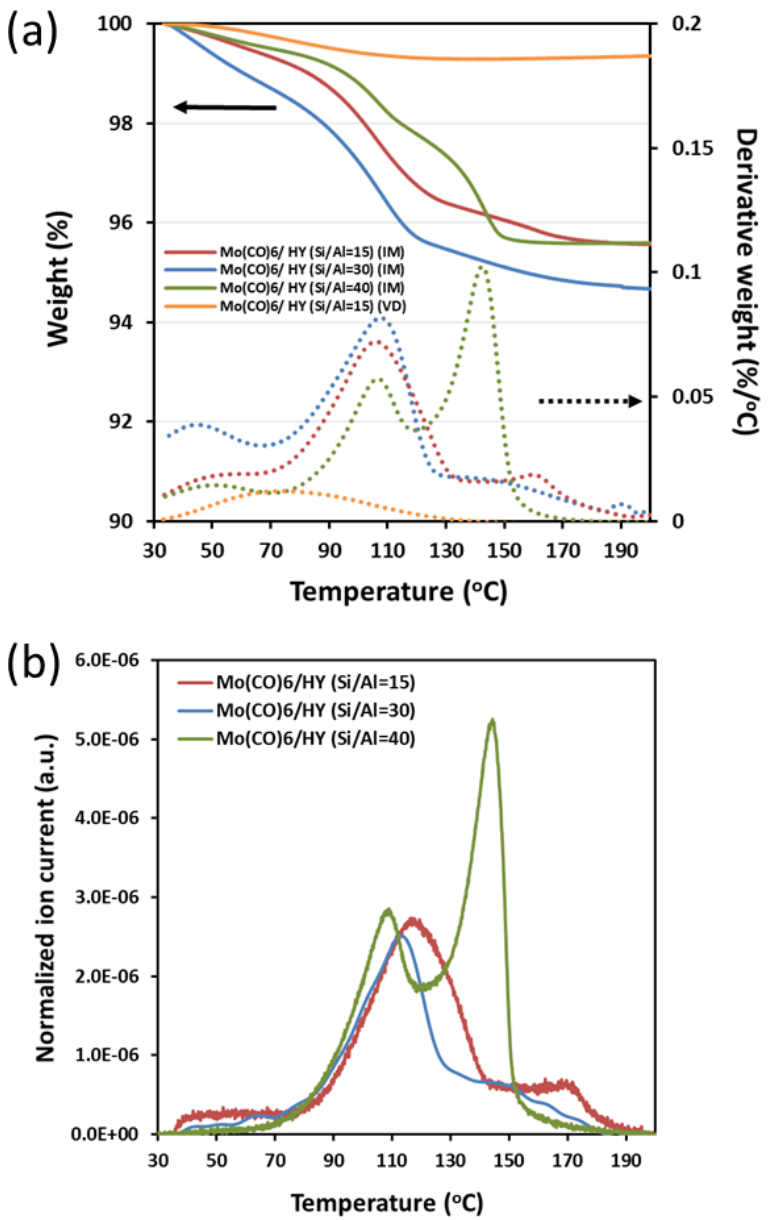

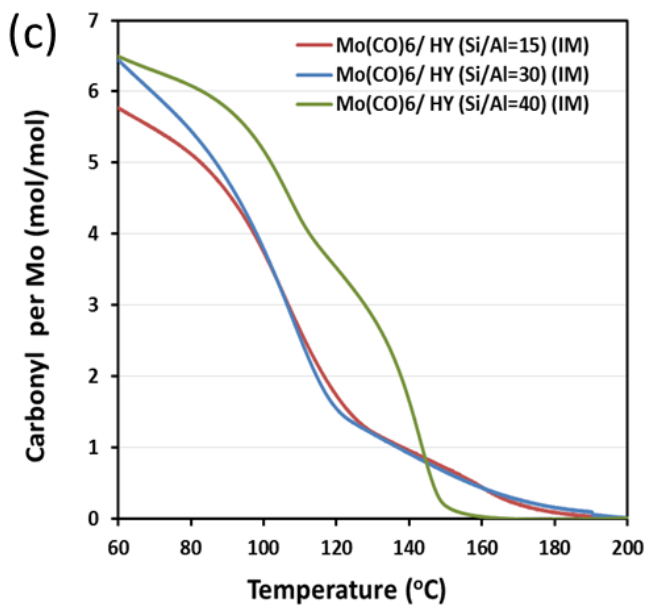

Fig. 3 (a) TGA results of the zeolite(HY)-supported $\mathrm{Mo}(\mathrm{CO})_{6}$. The catalysts were heated from 30 to $200^{\circ} \mathrm{C}$ in $\mathrm{He}\left(100 \mathrm{~mL} / \mathrm{min}, 5^{\circ} \mathrm{C} / \mathrm{min}\right)$. (b) Temperature profile of $\mathrm{m} / \mathrm{z}=28$ of evolved gasses; ion current normalized by Mo loading. (c) Calculated $\mathrm{CO}$ per Mo during heating, assuming all mass loss in this rage is from $\mathrm{CO}$, and is thus an upper limit. 

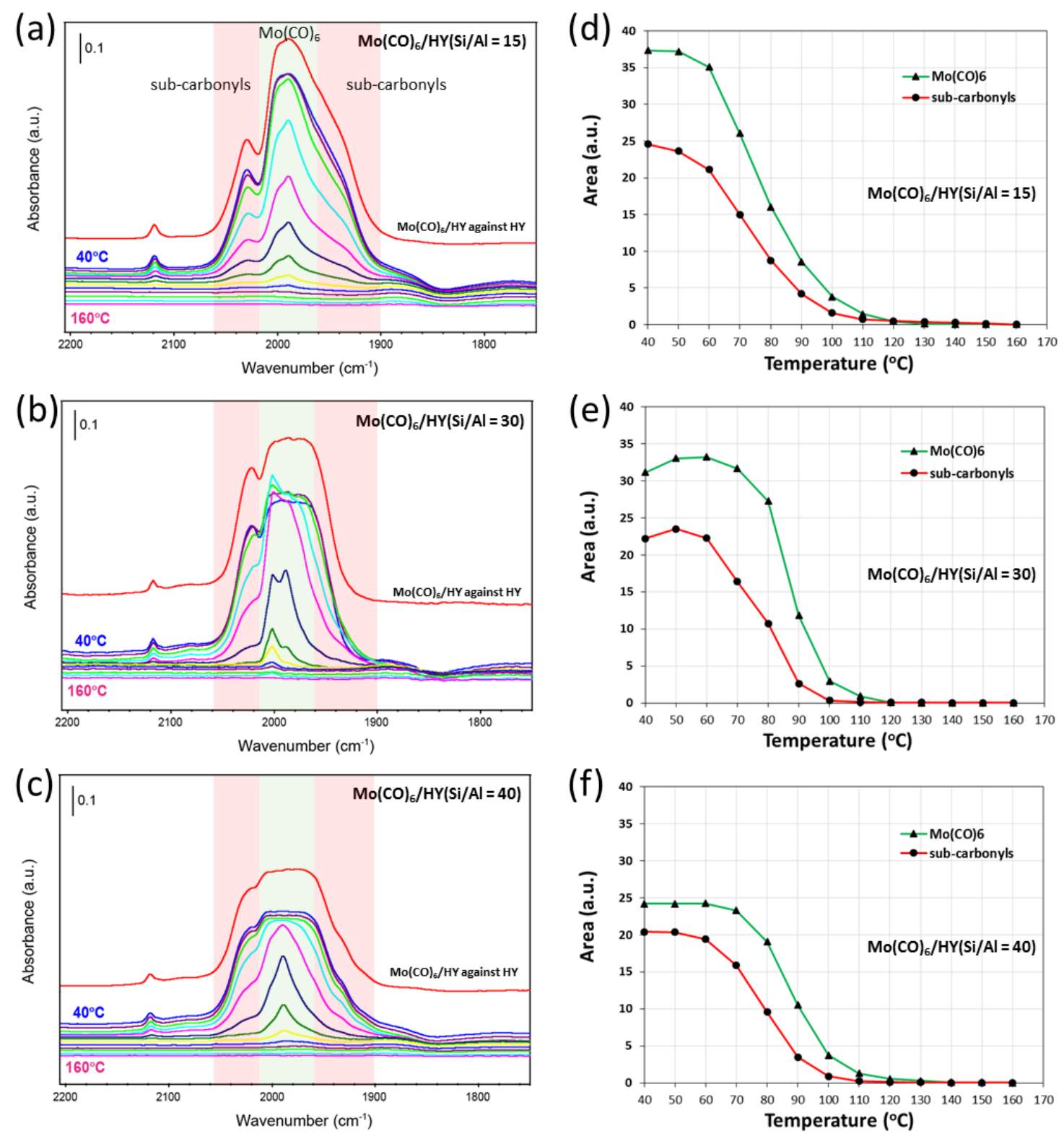

Fig. 4 FT-IR spectra of (a) $\mathrm{Mo}(\mathrm{CO})_{6} / \mathrm{HY}(\mathrm{Si} / \mathrm{Al}=15)$, (b) $\mathrm{Mo}(\mathrm{CO})_{6} / \mathrm{HY}(\mathrm{Si} / \mathrm{Al}=30)$, and (c) $\mathrm{Mo}(\mathrm{CO})_{6} / \mathrm{HY}(\mathrm{Si} / \mathrm{Al}=40)$ heated from 40 to $160^{\circ} \mathrm{C}$ under vacuum (20 mtorr). Prior to heating, the samples were held at 20 mtorr for $2 \mathrm{~h}$ to remove surface adsorbed water. The main set of spectra use the final catalyst heated to $170^{\circ} \mathrm{C}$ as the background. The integrated area between $2060-2015 \mathrm{~cm}^{-1}$ is assigned to $\mathrm{Mo}(\mathrm{CO})_{6}$, while the sum of areas between 2015-1960 $\mathrm{cm}^{-1}$ and 1960-1900 $\mathrm{cm}^{-1}$ is assigned as Mo sub-carbonyls. (d), (e) and (f) show the change of the integrated area of $\mathrm{Mo}(\mathrm{CO})_{6}$ and Mo sub-carbonyls during heating. 


\section{References:}

[1] J.R. Zoeller, E.M. Blakely, R.M. Moncier, T.J. Dickson, Catal. Today 36 (1997) 227241.

[2] C.-C. Yang, B.A. Kilos, D.G. Barton, E. Weitz, J.M. Notestein, J. Catal. 319 (2014) 211-219.

[3] A.L. Lapidus, S.D. Pirozhkov, A.R. Sharipova, A.N. Detyuk, R.V. Dmitriev, K.M. Minachev, B. Acad. Sci. USSR CH+ 27 (1978) 2351-2353.

[4] A.L. Lapidus, S.D. Pirozhkov, A. Vellekov, V.I. Garanin, P.I. Slyunyaev, K.M. Minachev, B. Acad. Sci. USSR CH+ 32 (1983) 119-124.

[5] G. P, C. G, P. M, I. B, Molecular Sieves II, American Chemical Society, 1977, pp. $144-$

155.

[6] S. Abdo, R.F. Howe, J. Phys. Chem. 87 (1983) 1713-1722.

[7] Y. Okamoto, A. Maezawa, H. Kane, T. Imanaka, J. Catal. 112 (1988) 585-589.

[8] Y. Okamoto, A. Maezawa, H. Kane, I. Mitsushima, T. Imanaka, J. Chem. Soc. Farad. T 184 (1988) 851-863.

[9] P.A. Cybulski, D.J. Gillis, M.C. Baird, Inorg. Chem. 32 (1993) 460-462.

[10] B.R. Muller, G. Calzaferri, J. Chem. Soc. Farad. T 92 (1996) 1633-1637.

[11] T. Yokota, M. Yaginuma, J.N. Kondo, K. Domen, C. Hirose, F. Wakabayashi, Catal. Lett. 40 (1996) 89-94.

[12] K. Asakura, Y. Noguchi, Y. Iwasawa, J. Phys. Chem. B 103 (1999) 1051-1058.

[13] Y. Okamoto, T. Kubota, Micropor. Mesopor. Mat. 48 (2001) 301-307.

[14] A.L. Fernandez, J.B. Hao, R.L. Parkes, A.J. Poe, E.J.S. Vichi, Organometallics 23 (2004) 2715-2723.

[15] K.P. Reddy, T.L. Brown, J. Am. Chem. Soc. 117 (1995) 2845-2854.

[16] Y.H. Yeom, B. Wen, W.M.H. Sachtler, E. Weitz, J. Phys. Chem. B 108 (2004) 5386-

5404.

[17] K. Kosma, S.A. Trushin, W. Fuss, W.E. Schmid, B.M.R. Schneider, Phys. Chem. Chem. Phys. 12 (2010) 13197-13214.

[18] R.N. Perutz, J.J. Turner, J. Am. Chem. Soc. 97 (1975) 4800-4804.

[19] Y. Ishikawa, C.E. Brown, P.A. Hackett, D.M. Rayner, J. Phys. Chem. 94 (1990) 2404-

2413.

[20] S. Ozkar, G.A. Ozin, K. Moller, T. Bein, J. Am. Chem. Soc. 112 (1990) 9575-9586.

[21] Y.S. Yong, R.F. Howe, J. Chem. Soc. Farad. T 182 (1986) 2887-2896.

[1] J.R. Zoeller, E.M. Blakely, R.M. Moncier, T.J. Dickson, Molybdenum catalyzed carbonylation of ethylene to propionic acid and anhydride, Catalysis Today, 36 (1997) 227-241.

[2] C.-C. Yang, B.A. Kilos, D.G. Barton, E. Weitz, J.M. Notestein, The role of iodide promoters and the mechanism of ethylene carbonylation catalyzed by molybdenum hexacarbonyl, Journal of Catalysis, 319 (2014) 211-219. 
[3] A.L. Lapidus, S.D. Pirozhkov, A.R. Sharipova, A.N. Detyuk, R.V. Dmitriev, K.M. Minachev, STATE OF PALLADIUM IN DEPOSITED PD-SIO2 CATALYSTS FOR CARBONYLATION OF ETHYLENE, Bulletin of the Academy of Sciences of the Ussr Division of Chemical Science, 27 (1978) 2351-2353.

[4] A.L. Lapidus, S.D. Pirozhkov, A. Vellekov, V.I. Garanin, P.I. Slyunyaev, K.M. Minachev, CARBONYLATION OF ETHYLENE BY CARBON-MONOXIDE ON METAL ZEOLITE CATALYSTS, Bulletin of the Academy of Sciences of the Ussr Division of Chemical Science, 32 (1983) 119-124.

[5] G. P, C. G, P. M, I. B, Adsorption and Decomposition of Metal Carbonyls Loaded in Y-Type Zeolite, in: Molecular Sieves?II, American Chemical Society, 1977, pp. 144155.

[6] S. Abdo, R.F. Howe, PREPARATION OF MOLYBDENUM ZEOLITES FROM MOLYBDENUM HEXACARBONYL .1. INFRARED STUDIES, J. Phys. Chem., 87 (1983) 1713-1722.

[7] Y. Okamoto, A. Maezawa, H. Kane, T. Imanaka, STOICHIOMETRY OF MOLYBDENUM SUBCARBONYL SPECIES ENCAGED IN NAY AND HY ZEOLITES, Journal of Catalysis, 112 (1988) 585-589.

[8] Y. Okamoto, A. Maezawa, H. Kane, I. Mitsushima, T. Imanaka, THERMAL STABILITIES OF HEXACARBONYL AND SUBCARBONYLS OF MOLYBDENUM ENCAPSULATED IN NAY AND NAX ZEOLITES, Journal of the Chemical SocietyFaraday Transactions I, 84 (1988) 851-863.

[9] P.A. Cybulski, D.J. Gillis, M.C. Baird, MO-95 T1 MEASUREMENTS OF MO(CO)6 ENCAPSULATED IN NA-Y ZEOLITE, Inorganic Chemistry, 32 (1993) 460-462.

[10] B.R. Muller, G. Calzaferri, Thin Mo(CO)(6)-Y-zeolite layers: Preparation and in situ transmission FTIR spectroscopy, Journal of the Chemical Society-Faraday Transactions, 92 (1996) 1633-1637.

[11] T. Yokota, M. Yaginuma, J.N. Kondo, K. Domen, C. Hirose, F. Wakabayashi, Reversible photodissociation of $\mathrm{Mo}(\mathrm{CO})(6)$ in a zeolite cage, Catalysis Letters, 40 (1996) 89-94.

[12] K. Asakura, Y. Noguchi, Y. Iwasawa, Stepwise synthesis and structure analysis of Mo dimers in NaY zeolite, Journal of Physical Chemistry B, 103 (1999) 1051-1058.

[13] Y. Okamoto, T. Kubota, Decarbonylation of group six metal carbonyl M(CO)(6) (M $=\mathrm{Cr}, \mathrm{Mo}, \mathrm{W}$ ) encaged in FAU zeolites: basicity of framework oxygen, Microporous and Mesoporous Materials, 48 (2001) 301-307.

[14] A.L. Fernandez, J.B. Hao, R.L. Parkes, A.J. Poe, E.J.S. Vichi, Zeolite activation of organometallics: Anchoring and decarbonylation kinetics of $\mathrm{Mo}(\mathrm{CO})(6)$ in dehydrated Na56Y zeolite, Organometallics, 23 (2004) 2715-2723.

[15] K.P. Reddy, T.L. Brown, KINETICS OF SURFACE PROCESSES FOR $\mathrm{MO}(\mathrm{CO})(6)$ ON PARTIALLY DEHYDROXYLATED ALUMINA AND HYDROXYLATED ALUMINA - OBSERVATION OF MO(CO)(5)(ADS), Journal of the American Chemical Society, 117 (1995) 2845-2854.

[16] Y.H. Yeom, B. Wen, W.M.H. Sachtler, E. Weitz, NOx reduction from diesel emissions over a nontransition metal zeolite catalyst: A mechanistic study using FTIR spectroscopy, Journal of Physical Chemistry B, 108 (2004) 5386-5404.

[17] K. Kosma, S.A. Trushin, W. Fuss, W.E. Schmid, B.M.R. Schneider, Photodissociation of group-6 hexacarbonyls: observation of coherent oscillations in an 
antisymmetric (pseudorotation) vibration in $\mathrm{Mo}(\mathrm{CO})(5)$ and $\mathrm{W}(\mathrm{CO})(5)$, Phys. Chem. Chem. Phys., 12 (2010) 13197-13214.

[18] R.N. Perutz, J.J. Turner, PHOTOCHEMISTRY OF GROUP-6 HEXACARBONYLS IN LOW-TEMPERATURE MATRICES 4. TETRACARBONYLMOLYBDENUM AND TRICARBONYLMOLYBDENUM, Journal of the American Chemical Society, 97 (1975) 4800-4804.

[19] Y. Ishikawa, C.E. Brown, P.A. Hackett, D.M. Rayner, EXCIMER LASER PHOTOLYSIS OF GROUP-6 METAL-CARBONYLS IN THE GAS-PHASE, J. Phys. Chem., 94 (1990) 2404-2413.

[20] S. Ozkar, G.A. Ozin, K. Moller, T. Bein, INTRAZEOLITE METAL-CARBONYL TOPOTAXY - A COMPREHENSIVE STRUCTURAL AND SPECTROSCOPIC STUDY OF INTRAZEOLITE GROUP-VI METAL HEXACARBONYLS AND SUBCARBONYLS, Journal of the American Chemical Society, 112 (1990) 9575-9586.

[21] Y.S. Yong, R.F. Howe, ADSORPTION AND DECOMPOSITION OF MO(CO)6 IN ZEOLITE NAY, Journal of the Chemical Society-Faraday Transactions I, 82 (1986) 2887-2896. 